ISSN 1112-9867

Available online at

http://www.jfas.info

\title{
COMPARED PERFORMANCES OF THE EXPERIMENTAL DIGESTERS OF THE ANIMAL BIOMASS
}

\author{
Y. M'Sadak *, A. Ben M'Barek \\ Department of the Genius of the Horticultural Systems and the Natural Environment \\ Higher Agronomic Institute of Chott-Mariem, University of Sousse, Tunisia
}

Received: 26 August 2013 / Accepted: 5 March 2014 / Published online: 30 June 2014

\begin{abstract}
ABSRACT
This study proposes to look further into experimentally of the effect of the variation of certain physicochemical parameters of anaerobic digestion on the quantitative gas productivity of four digesters of treating bovine dejections. Moreover, four digesters supplied with the avicolous droppings, in different concentrations of Dry Matter (DM), were followed. The assessments of depollution (Suspended Matter and Biological Demand for Oxygen) together with qualitative energy (gas composition and calorific value) were also appreciated. We can release particularly that: the quantity of bovine biogas produced is variable according to the parameters of digestion. It is maximum in the presence of high temperature and under mechanical agitation of the substrate introduced; the quantitative productivity is more interesting in the case of the digesters avicolous. It is more important with the increase of the concentration of solids; the digester with 8\% DM presents attractive valuations of depollution and energy efficiency.
\end{abstract}

Keywords: Experimental biomethanisation; animal dejections; environmental performance; gas quantitative production; composition to methane; calorific value.

Author Correspondence, e-mail: msadak.youssef@yahoo.fr

Tel.: +21332223013; fax: +21332223013.

ICID: 1111568 


\section{INTRODUCTION}

Energy recovery from waste is not a new field of study, but its implementation continues to be a challenge in some Arab countries [1]. Increasing global demand for fossil fuels is facing the prospect of depletion of these resources creating tensions on the energy markets [2], which represents, today, an important challenge for sustainable development [3; 4]. Indeed, more than $80 \%$ of the consumption of primary energy is based on fossile fuels and the share is likely to remain high in the future. To meet the energy needs, the prospection and the development of new energy sources were undertaken in particular that of the biomass $[5 ; 6 ; 7 ; 8]$. Biomass is a field in constant increase and has a wide diversity of composition. Its operations for the production of energy of biomass, is particularly interesting because it also involved in the preservation of the environment $[9 ; 10 ; 11]$. In Tunisia, the performance of the Biogas effluents applied to intensive livestock were evaluated at different scales: Experimental [12], rural [13] and industrial [14].

The waste processing became a paramount need for environmental protection [15]. As a renewable energy producer process, the biomethanisation takes part in the reduction of the emissions of Gases for Greenhouse effect noted GGE [16; 17; 18; 19; 20]. The good performance (depollution, potentiality of energy) of this kind of process of treatment of Organic Matter (OM) is conditioned largely by the adopted mode of digestion and the physicochemical conditions of the substrate put in fermentation, inter alia, its nature, the temperature, agitation, the $\mathrm{pH}$ and the Dry Matter (DM). The two modes of digestion (into discontinuous and uninterrupted) were tested on the level of four experimental digesters, supplied respectively for the first time by bovine dungs and another time by avicolous droppings. Thus, for the digesters, supports of this study, a follow-up of some physicochemical parameters ( $\mathrm{pH}$ and $\mathrm{DM}$ ) was established all the way along process of biomethanisation (launching and production phases).

In the optics of the control of the conditions of the fermentaire medium for a better environmental and energy valorization, this study proposes the evaluation on an experimental scale, on the one hand, of the assessment of depollution of the avicolous droppings treated by biomethanisation, in terms of Suspended Matter (SM) and Biological Demand for Oxygen $\left(\mathrm{BDO}_{5}\right)$, and on the other hand, of the quantitative gas productivity as a whole, in order to compare the potential quantitative energy of two substrates considered. Moreover, the potential qualitative energy 
(composition and calorific value) of the biogas produced starting from the poultry droppings was also studied.

\section{MATERIAL AND METHODS}

\subsection{EXPERIMENTAL SITE}

The work committed consists in implementing the experimentation of the biomethanisation of the animal biomass in eight experimental pilot digesters (two units) installed at the laboratory "Biogas" of the Agricultural Professional Training Center of Bovine Breeding (A.P.T.C.B.B) of Sidi Thabet, Tunisia.

\subsection{EXPERIMENTAL MATERIAL}

\subsubsection{RAW MATERIALS PUT IN FERMENTATION}

The experimentation carried, on the one hand, on fresh dungs produced by the cows available (like substrate) and of the black bovine dungs extracted the septic tank adopted (like inoculum), and on the other hand, on fresh avicolous droppings brought back from the Agricultural Professional Training Center in Poultry Farming (A.P.T.C.P.F.) of Sidi Thabet, used like substrate and on pre-fermented bovine dungs (or black dungs) diluted used like inoculum. The characteristics of the raw materials tested are presented in table 1 hereafter.

Table 1. Characteristics of the substrates used

\begin{tabular}{|l|l|l|l|l|}
\hline & & Raw materials & $\% \mathrm{DM}$ & $\mathrm{pH}$ \\
\hline \multirow{2}{*}{ Bovine Experimentation } & Substrate & Fresh dungs & 31.5 & 6.5 \\
\cline { 2 - 6 } & Inoculum & Black dungs & 9.4 & 7.2 \\
\hline \multirow{2}{*}{ Avicolous Experimentation } & Substrate & Avicolous droppings & 20.9 & 8.7 \\
\cline { 2 - 6 } & Inoculum & Black dungs & 4.0 & 7.2 \\
\hline
\end{tabular}

\subsubsection{EXPERIMENTAL DEVICE}

The work committed consists in implementing the experimentation of the biomethanisation of the bovine dungs and the avicolous droppings, while following two processes of fermentation which are respectively into discontinuous and uninterrupted experimental pilot digesters installed (Figure 1). 


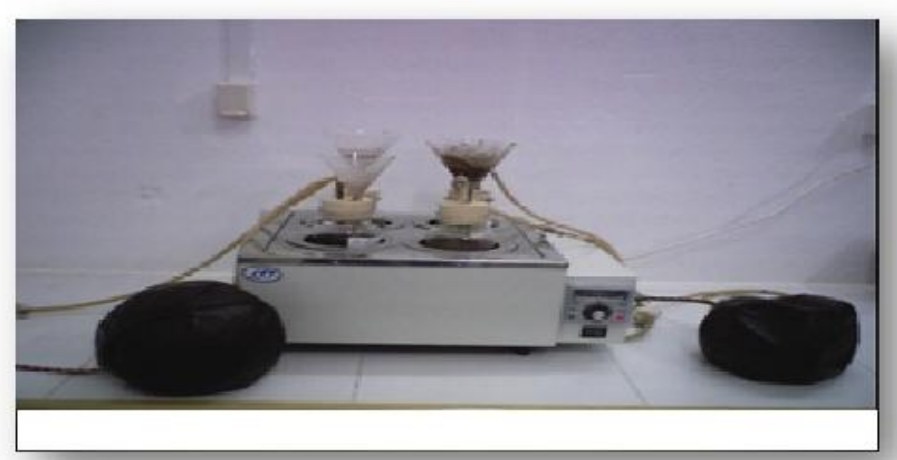

Fig.1. Experimental device of digestion adopted.

The first four digesters, different from point of view parameters of operation, were useful for the follow-up of the physicochemical parameters and the quantitative production of the biogas produced starting from the bovine biomass. The four second digesters used contain avicolous droppings with various concentrations in DM (Table 2) by having recourse to the dilution of the brought back droppings. They were useful for the follow-up of the environmental potentiality and the quantitative and qualitative productions of biogasstarting from the avicolous biomass. The characteristics of these digesters are consigned in table 2.

Table 2. Generalities about the parameters of operation of differentdigesters employed

\begin{tabular}{|c|c|c|c|c|}
\hline & Digesters & Raw materials & Temperature $\left({ }^{\circ} \mathrm{C}\right)$ & Agitation \\
\hline \multirow{4}{*}{$\begin{array}{l}\text { Bovine } \\
\text { Experimentation } \\
\text { (Discontinuous) }\end{array}$} & Experimental I & Fresh dungs & \multirow[b]{2}{*}{25} & Without \\
\hline & Experimental II & $\begin{array}{l}\text { Fresh and black } \\
\text { dungs }\end{array}$ & & Without \\
\hline & Experimental III & \multirow{2}{*}{ Fresh dungs } & \multirow{2}{*}{35} & Without \\
\hline & Experimental IV & & & With \\
\hline \multirow{4}{*}{$\begin{array}{l}\text { Avicolous } \\
\text { Experimentation } \\
\text { (Uninterrupted) }\end{array}$} & Experimental I & \multirow{4}{*}{$\begin{array}{l}\text { Substrate: Avicolous } \\
\text { droppings } \\
\text { respectively } 3,6,8 \\
\text { and } 16 \% \text { DM. } \\
\text { Inoculum: Fresh } \\
\text { dungs }\end{array}$} & \multirow{4}{*}{35} & \multirow{4}{*}{ With } \\
\hline & Experimental II & & & \\
\hline & Experimental III & & & \\
\hline & Experimental IV & & & \\
\hline
\end{tabular}




\subsection{Phases of filling of the digesters and starting of fermentation}

The starting of the anaerobic digestion is a critical phase in the production of biogas; therefore it must be quite neat so that the process begins most quickly than possible.

There exist two processes of anaerobic digestion which correspond to two fundamental types of digesters. The digester of the discontinuous type is supplied intermittently with strawy substrates which can be drowned in a liquid manure of methanogens bacteria, the production of biogas is discontinuous, and at the end of the digestion, the substrate has the texture of the manure of farm (compost). The digester is known as continuous when it is fed regularly in the course of fermentation with a liquid substrate, the production of biogas is then continuous [21].

The experimental biomethanisation into discontinuous requires thus only one contribution in substrate, inoculum and water at the beginning of the process. Once the filling is carried out, the digester must be tight to ensure the anaerobiose as well as the good progress of fermentation. During this phase, two volumes of water a were introduced against a volume of dung.

For the biomethanisation uninterrupted, the quantities of droppings introduced and evacuated daily are about $45 \mathrm{ml}$ for each digester. We carried out a followed daily extraction of digested droppings by the introduction of the same volume, and this until the totality of the contents of the digester will be renewed. After the launching phase (10 days), the quantity of inoculum was completely extracted following the daily renewal carried out. At this stage, the supply-extraction related only to the fresh droppings.

Table 3 mentions the quantities of each raw material introduced into all the digesters used during the experimentation. 
Table 3. Quantities of substrate, inoculum and water introduced

\begin{tabular}{|l|c|c|c|}
\hline \multicolumn{1}{|c|}{ Digester } & Substrate $(\mathrm{ml})$ & Inoculum $(\mathrm{ml})$ & Water $(\mathrm{ml})$ \\
\hline Experimental bovin I & 100 & - & 200 \\
\hline Experimental bovin II & 60 & 30 & 180 \\
\hline Experimental bovin III & 100 & - & 200 \\
\hline Experimental bovin IV & 100 & - & 200 \\
\hline Experimental avicolous I & 45 & 150 & 305 \\
\hline Experimental avicolous II & 120 & 150 & 230 \\
\hline Experimental avicolous III & 170 & 150 & 180 \\
\hline Experimental avicolous IV & 380 & 100 & 20 \\
\hline
\end{tabular}

\subsection{Experimental follow-up}

For each digester, the follow-up related to several physicochemical, environmental and energy parameters for one variable period between one to four weeks according to the performances raised of digestion.

The environmental parameters in which we were interested are relating to the polluting load: Rate of Suspended Matter (SM) and the Biological Demand for Oxygen $\left(\mathrm{BDO}_{5}\right)$.

For the SM, they correspond to the whole of mineral and/or organic particles present in a natural or polluted water [22]. Its determination makes it possible to consider the bacterial biomass in the digester [23]. The analysis rests on the principle of quantifying all the matters being able to be decantable after elimination of the major part of water by filtration and evaporation in the drying oven with $105^{\circ} \mathrm{C}$.

Concerning the $\mathrm{BDO}_{5}$, this parameter constitutes a good indicator of the content of a biodegradable $\mathrm{OM}$ in water during processes of purification. As any polluting biodegradable $\mathrm{OM}$ involves an oxygen uptake $\left(\mathrm{O}_{2}\right)$, the principle of the measurement of the $\mathrm{BDO}_{5}$ rests, then, on the quantification of $\mathrm{O}_{2}$ consumed after incubation of the sample during five days.

For the quantification, we had a vat filled with water in which we installed beakers graduated to recover produced gas (Figure 2). The gas will drive out water and take its place, from where; we can directly read the quantity produced starting from the graduations. 


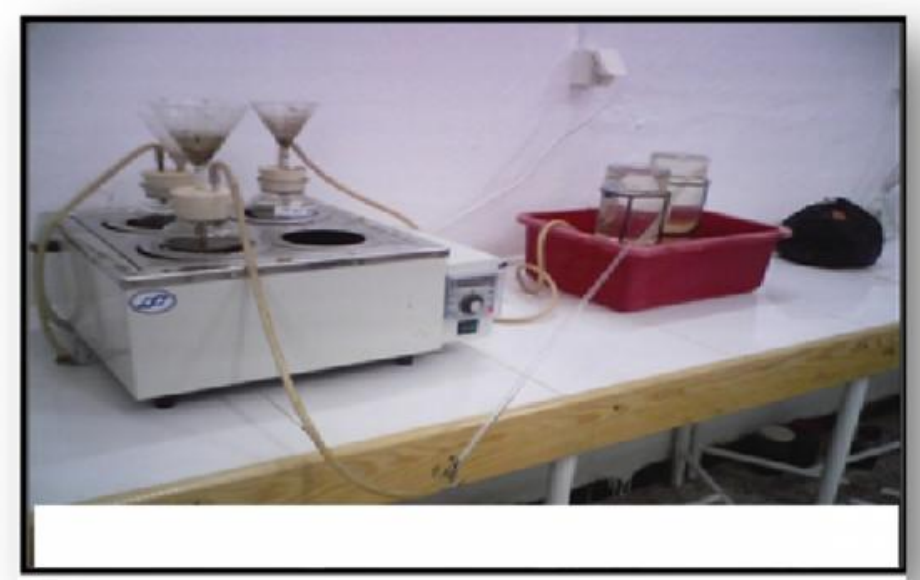

Fig.2. System of quantitative follow-up of experimental biogas

The taking away of biogas was carried out by calling upon a simple system based on samplings in bladders of balloon. For the analysis of the gas composition, we had recourse to the technique of Gas chromatography. This technique is suitable for the compounds gas or likely to be vaporized by heating without decomposition. The components determined by this method are $\%$ $\mathrm{CH}_{4}, \% \mathrm{CO}_{2}$ and $\% \mathrm{H}_{2} \mathrm{~S}$.

Moreover, we were also interested in the potential energy, by considering the lower (LCV) and higher $(\mathrm{HCV})$ values of the calorific value, expressed in $\mathrm{kWh} / \mathrm{m}^{3}, \mathrm{kcal} / \mathrm{m}^{3}$ or $\mathrm{kcal} / \mathrm{kg}$ and which is connected by the following expression:

$$
\mathrm{HCV}=\mathrm{LCV}+\text { heat of vaporization }
$$

\section{RESULTS AND DISCUSSION}

\subsection{FOLLOW-UP OF THE EVOLUTION OF THE PH DURING THE EXPERIMENTS IMPLEMENTED}

\subsubsection{IMPORTANCE OF THE STUDY OF PARAMETER PH}

It is admitted that the $\mathrm{pH}$ is the first indicator of the faulty possible operation of a digester. If the $\mathrm{pH}$ is below 6.5, the addition of the sodium lime or bicarbonate corrects this anomaly [24]. The 
optimum $\mathrm{pH}$ of anaerobic digestion is around neutrality, it is from 6.8 to 7.5. If the value of the $\mathrm{pH}$ is lower than 6.5 or higher than 7.5, the bacteria will then be inhibited [25].

\subsubsection{FOLLOW-UP OF THE PH ON THE LEVEL OF THE BOVINE EXPERIMENTATION}

The figure 3 illustrates the various curves of evolution of the $\mathrm{pH}$ on the level of four experimental digesters supplied with discontinuous, while showing the incidence compared of certain physicochemical parameters (inoculum, agitation and temperature) on the $\mathrm{pH}$ recorded.

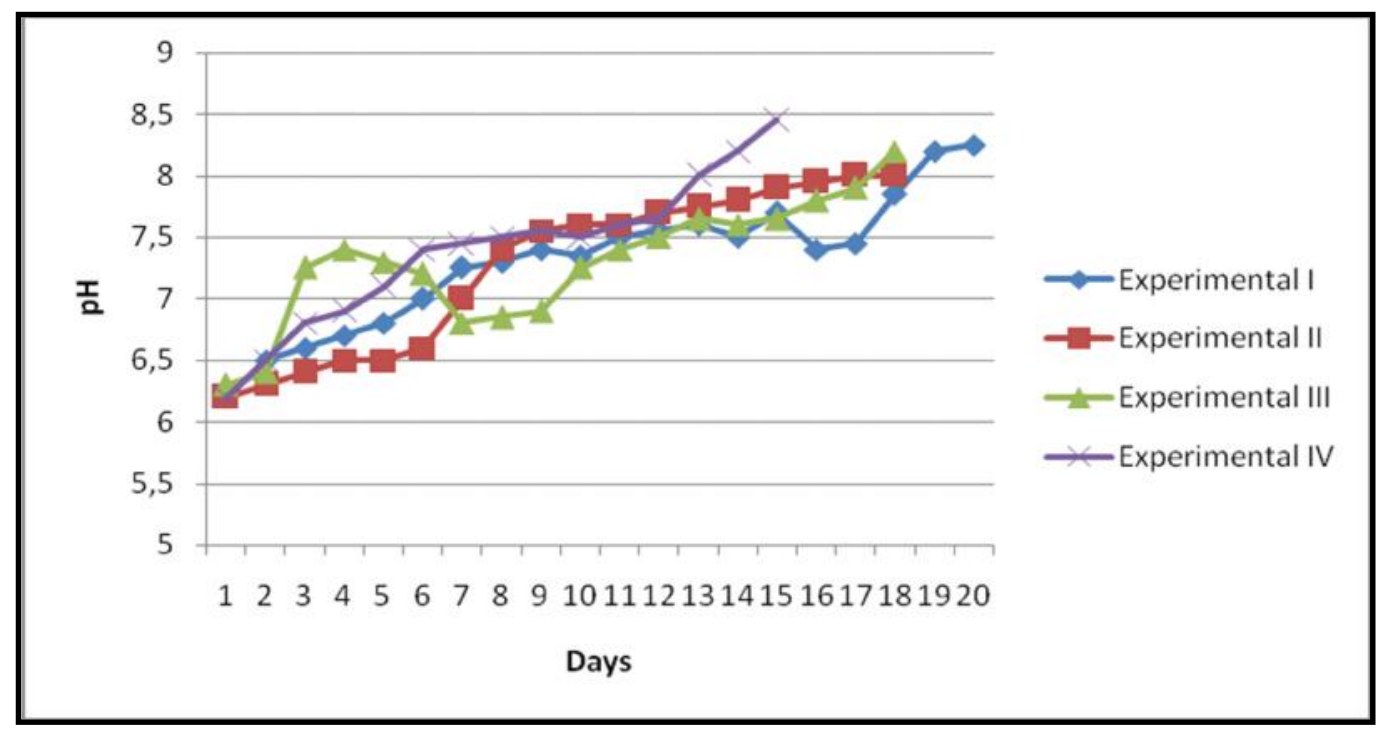

Fig.3. Evolution of the $\mathrm{pH}$ on the level of various digesters

The addition of the inoculum does not have much influence on the evolution of the $\mathrm{pH}$ of the two digesters I and II, respectively without and with inoculum, which presents almost the same behavior throughout the launching phase. This phase is essential for the constitution of the bacterial populations which will contribute to fermentation, and thereafter, will ensure a margin of $\mathrm{pH}$ allowing the production of biogas.

The correction of the $\mathrm{pH}$ was carried out as of the 1st day (considering the recorded initial $\mathrm{pH}$ was of 6.2) with a solution of $\mathrm{NaOH}$ to reach the advised minimum threshold of 6.5.

The addition of the inoculum does not have much influence on the evolution of the $\mathrm{pH}$ of the two digesters I and II, respectively without and with inoculum, which presents almost the same behavior throughout the launching phase. This phase is essential for the constitution of the 
bacterial populations which will contribute to fermentation, and thereafter, will ensure a margin of $\mathrm{pH}$ allowing the production of biogas.

The correction of the $\mathrm{pH}$ was carried out as of the 1 st day (considering the recorded initial $\mathrm{pH}$ was of 6.2) with a solution of $\mathrm{NaOH}$ to reach the advised minimum threshold of 6.5.

In addition, it is noticed that mechanical agitation has a considerable effect on the increase of the values of the $\mathrm{pH}$ and on the speed of the process of fermentation by comparing the state of development of the $\mathrm{pH}$ with the level of digesters III (not agitated) and IV (agitated).

Concerning the temperature, it has a more or less considerable effect on the increase of the values of the PH. This effect is appreciated through the follow-up of the variation of the $\mathrm{pH}$ on the level of digesters I and III.

\subsubsection{FOLLOW-UP OF THE PH ON THE LEVEL OF THE AVICOLOUS EXPERIMENTATION}

\subsubsection{LAUNCHING PHASE}

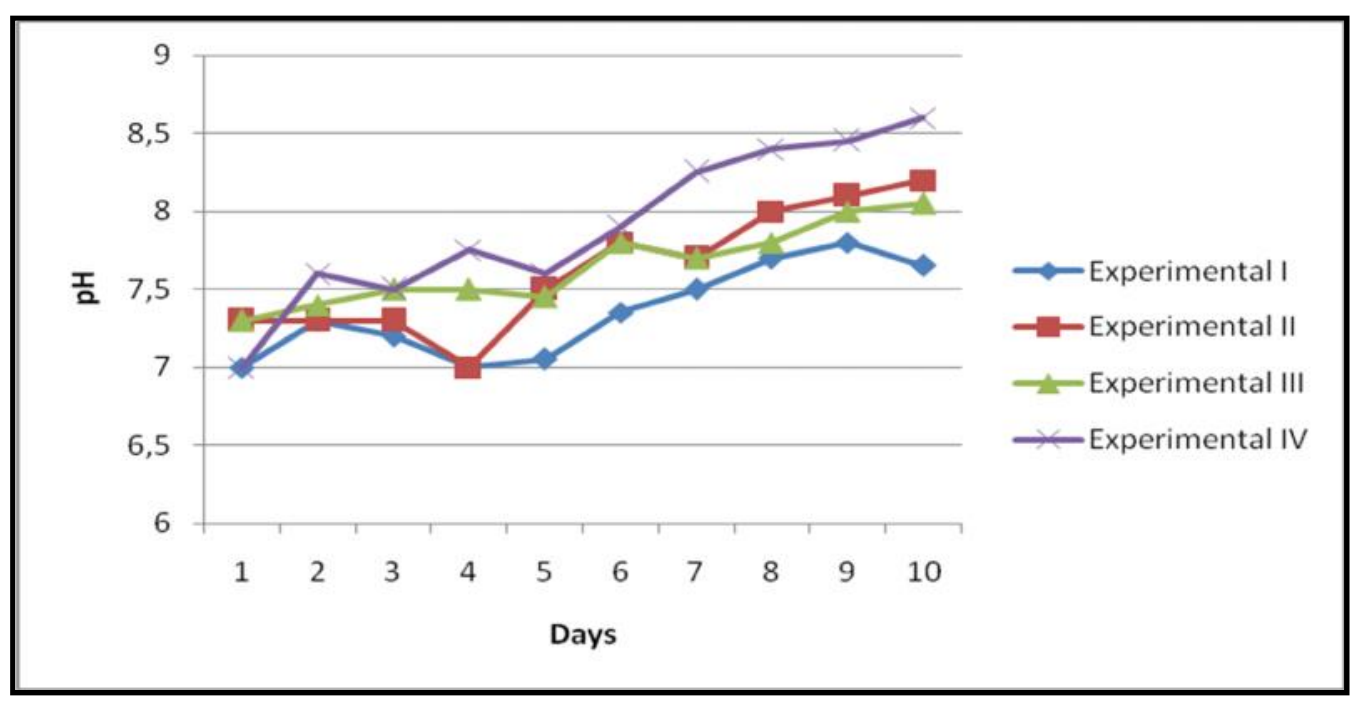

Fig.4. Evolution of the $\mathrm{pH}$ during the launching phase

The starting of this kind of uninterrupted process is very delicate and requires the culture of the methanogens bacteria. The use of an inoculum with $\mathrm{pH}$ close to neutrality and the application to a periodic load to substrate prove to be necessary for the stability of the launching phase. The goal of this preparatory phase thus consists in adapting the methanogens bacteria of black dungs of 
cows to their new fermentaire medium (avicolous droppings to digest). The figure 4 shows the variations of the $\mathrm{pH}$ during the launching phase, which was limited to 10 days, on the level of the four digesters implemented.

Among all the digesters, only digester I proved presenting values of $\mathrm{pH}$ close to reality, whereas the others presented exceeding values of $\mathrm{pH}$, in most case, the threshold value of production of gas which is of 7.5. This could be explained, on the one hand, by the significant amount of water distilled present in digester I, and on the other hand, by the small quantity of matters to be digested. For the other digesters, more the concentration in DM of the introduced droppings is important, more the value of the $\mathrm{pH}$ tends to rise, considering the basic value of the $\mathrm{pH}$ of the wet avicolous droppings.

\subsubsection{PHASE OF GAS PRODUCTION}

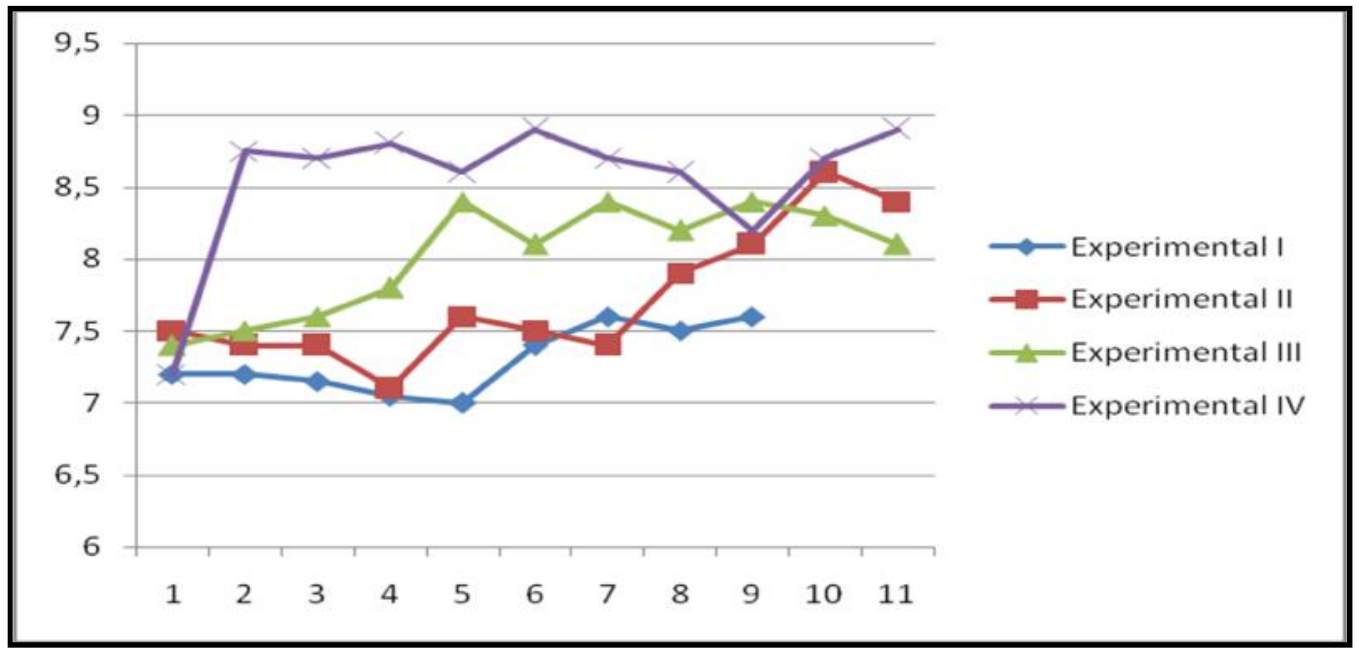

Fig.5. Evolution of the $\mathrm{pH}$ during the phase of gas production

During this phase the production on the level of digester I was limited to the first 10 days and the values of $\mathrm{pH}$ lay between 7 and 7.5, values answering the output norms of biogas established by [25]. We judged to stop the experimentation at this stage, because of the insufficiency quantity of the biogas produced.

The evolution of the $\mathrm{pH}$ on the level of digesters II and III (Figure 5) is constantly increasing with a light shift of two curves as from the 4th day, because the quantity of fresh droppings added each day is higher for digester III than that for digester II. As for digester IV, the values of the $\mathrm{pH}$ 
are definitely high, which explains the small produced quantity of biogas by this digester at this stage. At the end of a few days, the follow-up of this digester is not interesting any more, since it proved that the small quantity of gas produced cannot be enough for the qualitative analysis gas.

\subsection{DETERMINATION OF THE DM DURING THE EXPERIMENTS IMPLEMENTED}

\subsubsection{FOLLOW-UP OF THE VARIATION OF THE DM ON THE LEVEL OF THE} BOVINE EXPERIMENTATION

The analysis results are summarized \% DM for various autoclaves, respectively as follows: 15.8, 13.6, 16.6 and 15.3.

The objective sought during this experimentation was the comparison of the biomethanisation, while varying certain parameters (inoculum, agitation and temperature) while keeping as much as possible similar experimental conditions $(\mathrm{pH}, \mathrm{DM} \ldots$...). The results obtained makes it possible to note that \% DM are almost similar in the level of all the digesters. The highest value of DM was recorded in the case of digester III.

\subsubsection{FOLLOW-UP OF THE EVOLUTION OF THE DM ON THE LEVEL OF THE AVICOLOUS EXPERIMENTATION}

The first catch was carried out after 10 days (end of the launching phase), the following catches of samples followed each week (interval of one week) to make sure that \% of DM did not vary during the phase of supply-extraction. The table 4 shows the results raised for the DM for each taking away.

Table 4. Evolution of the \% DM during avicolous fermentation

\begin{tabular}{|l|c|c|c|}
\hline \multirow{2}{*}{ Digester } & \multicolumn{3}{|c|}{ \% DM } \\
\cline { 2 - 4 } & 1st catch & 2nd catch & 3rd catch \\
\hline Experimental I & 3.3 & 6.0 & 6.1 \\
\hline Experimental II & 5.9 & 8.0 & 8.0 \\
\hline Experimental III & 7.9 & 16.4 & - \\
\hline Experimental IV & 16.6 & & - \\
\hline
\end{tabular}


According to the results obtained, we can say that the values of DM are almost stable and did not vary in the course of time. The light variations recorded are negligible and prove the good progress of the process of fermentation, and particularly, the supply-extraction.

\subsection{ENVIRONMENTAL PERFORMANCE EVALUATION OF THE AVICOLOUS EXPERIMENTATION}

The figure 6 illustrates the results of the environmental analyzes relating to $\mathrm{SM}$ and the $\mathrm{BDO}_{5}$ carried out before and after fermentation and presented in the form of assessments of depollution. The consistency of the digesters in DM influences considerably the assessment of depollution as of $\mathrm{SM}$ and of the $\mathrm{BDO}_{5}$. Indeed, more the $\mathrm{DM}$ is important; more the reduction of the polluting load is increasing. This observation is valid provided that the concentration in DM does not exceed $10 \%$ [26], which is confirmed by the results raised for the digester IV $(16 \% \mathrm{DM})$ whose assessment of the $\mathrm{BDO}_{5}$ is weaker than that of digester III to $8 \% \mathrm{DM}$ which presents the best assessment of depollution.

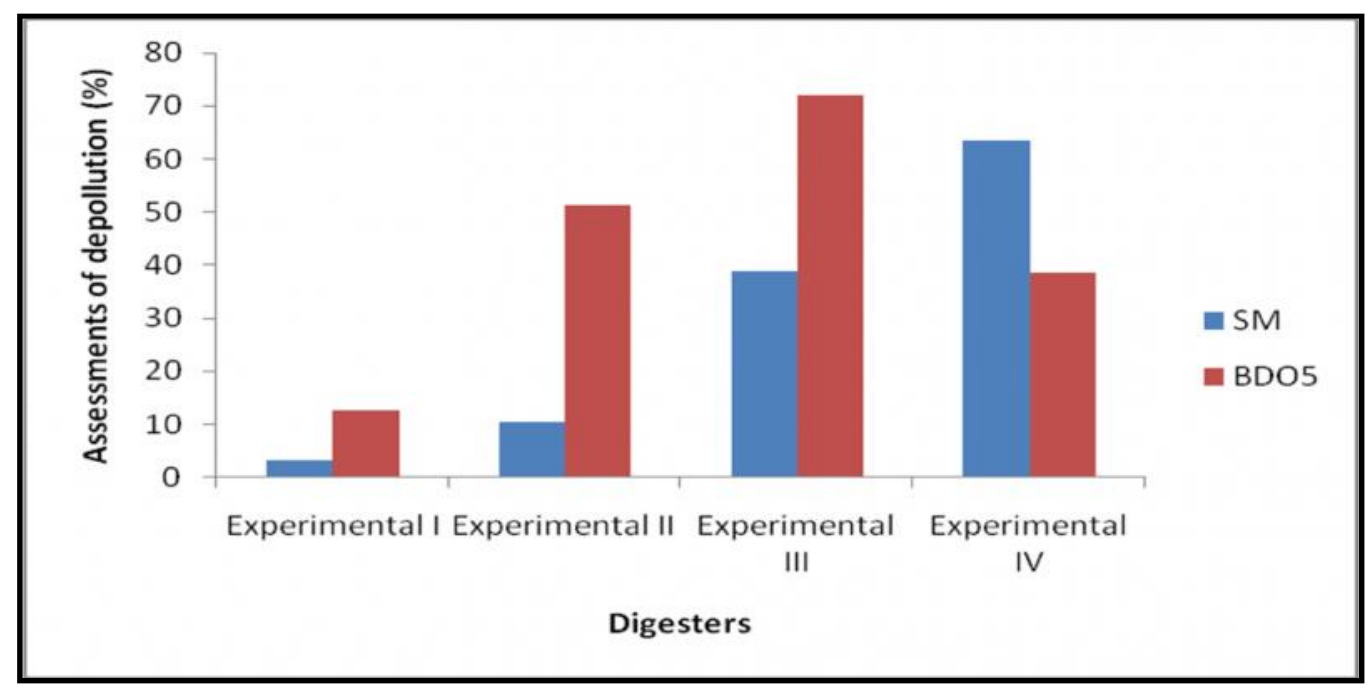

Fig.6. Variation of the reduction of the polluting load following the biomethanisation

The assessments of digesters I and II as non satisfactory. This can be due to the great quantity of water present and also to the short duration of operation (case of digester I). These two digesters called upon concentrations in relatively weak DM $(\leq 6 \%)$. From $8 \%$ DM (digester III), the reduction as of SM is interesting and it continues its increase. On this subject, the best assessment is observed on the level of digester IV, presenting $16 \%$ DM. This result cancels the assertion of [26] quoted previously. 


\subsection{QUANTITATIVE ENERGY PERFORMANCE EVALUATION OF THE DIGESTERS IMPLEMENTED}

\subsubsection{QUANTITATIVE FOLLOW-UP OF THE GAS PRODUCTIVITY DURING THE BOVINE EXPERIMENTATION}

The production of gas on the level of the experimental digesters, led into discontinuous, began after the launching phase, with an increasing quantity gradually to reach a maximum level of production, then it started to fall quickly (Figure 7).

The entry in production of biogas for digester II (with inoculum) began as soon as the limit lower value suitable $\mathrm{pH}$ for the production of biogas was reached (the 5th day). Contrary, in the case of digester I (without inoculum), the launching phase presented suitable values of $\mathrm{pH}$ for the production of biogas, but there biogas produced was only the 7 th day. This result could be probably due to the bacterial populations not yet adapted.

The fast entry in production of digester II is due to the presence of black dung which guaranteed the existence of the bacterial populations and which supported a little higher total quantity of production in favor of digester II (141 $\mathrm{ml}$ of biogas produced against $136 \mathrm{ml}$ for digester I).

The considerable effect of agitation in a digester is due to the fact that it supports the provisioning of nutritive substances to the bacteria and their transport with the fresh substrate, lately introduced. It induced a speed and an effectiveness of the production process on the level of digester IV agitated (187 $\mathrm{ml}$ of produced biogas) in comparison with digester III not agitated (134 ml).

The follow-up of the effect of the increase in the temperature on the course of the production process of biogas can be appreciated by comparing the curves of evolution of the productivity of two digesters $\mathrm{I}\left(\mathrm{T}^{\circ}=25^{\circ} \mathrm{C}\right)$ and III $\left(\mathrm{T}^{\circ}=35^{\circ} \mathrm{C}\right)$. More the temperature is higher, more the gas productivity is important and the production process is faster. 


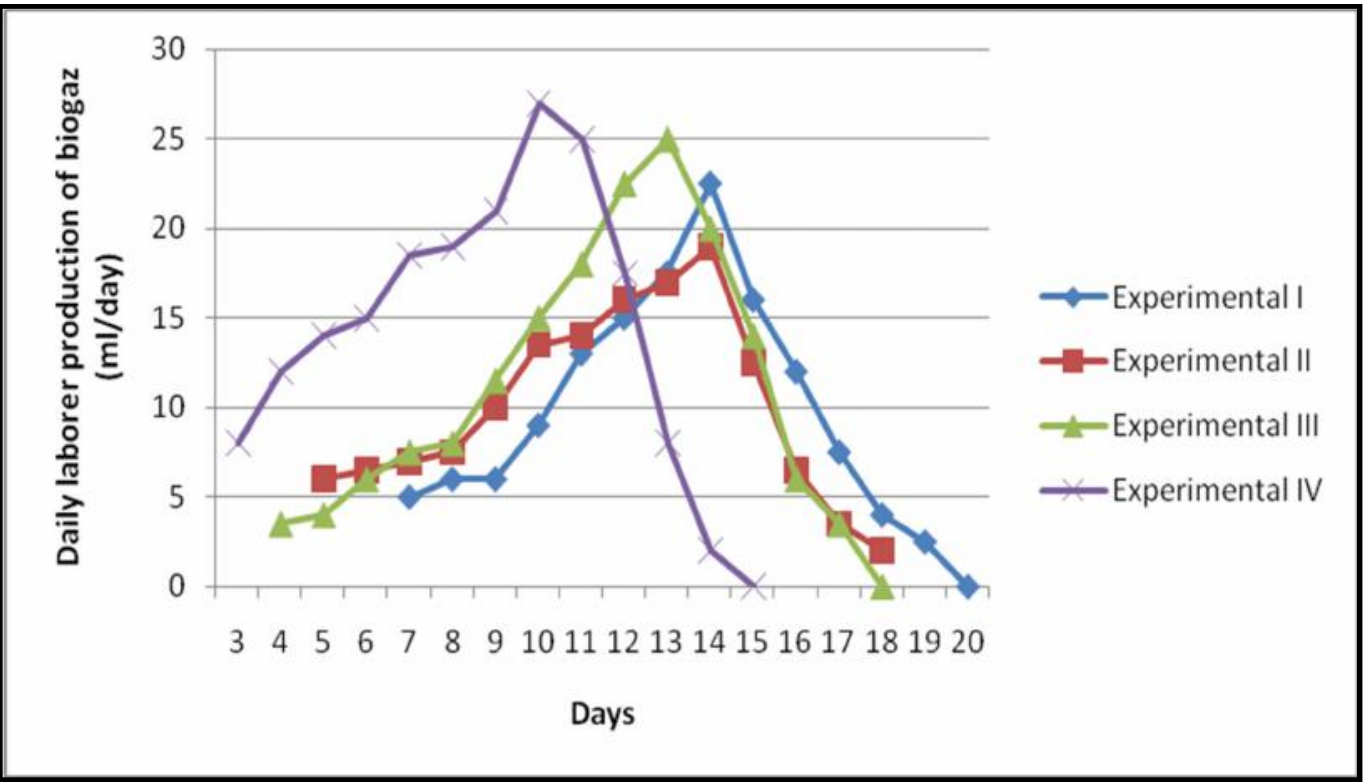

Fig.7. Evolution of the gas production in the course of time

\subsubsection{QUANTITATIVE FOLLOW-UP OF THE GAS PRODUCTIVITY DURING THE AVICOLOUS EXPERIMENTATION}

The follow-up was carried out just after the launching phase, i.e. after 10 days of the beginning of the experimentation implemented. The figure 8 presents the curves of production of biogas raised for the three functional digesters (non functional digester I).

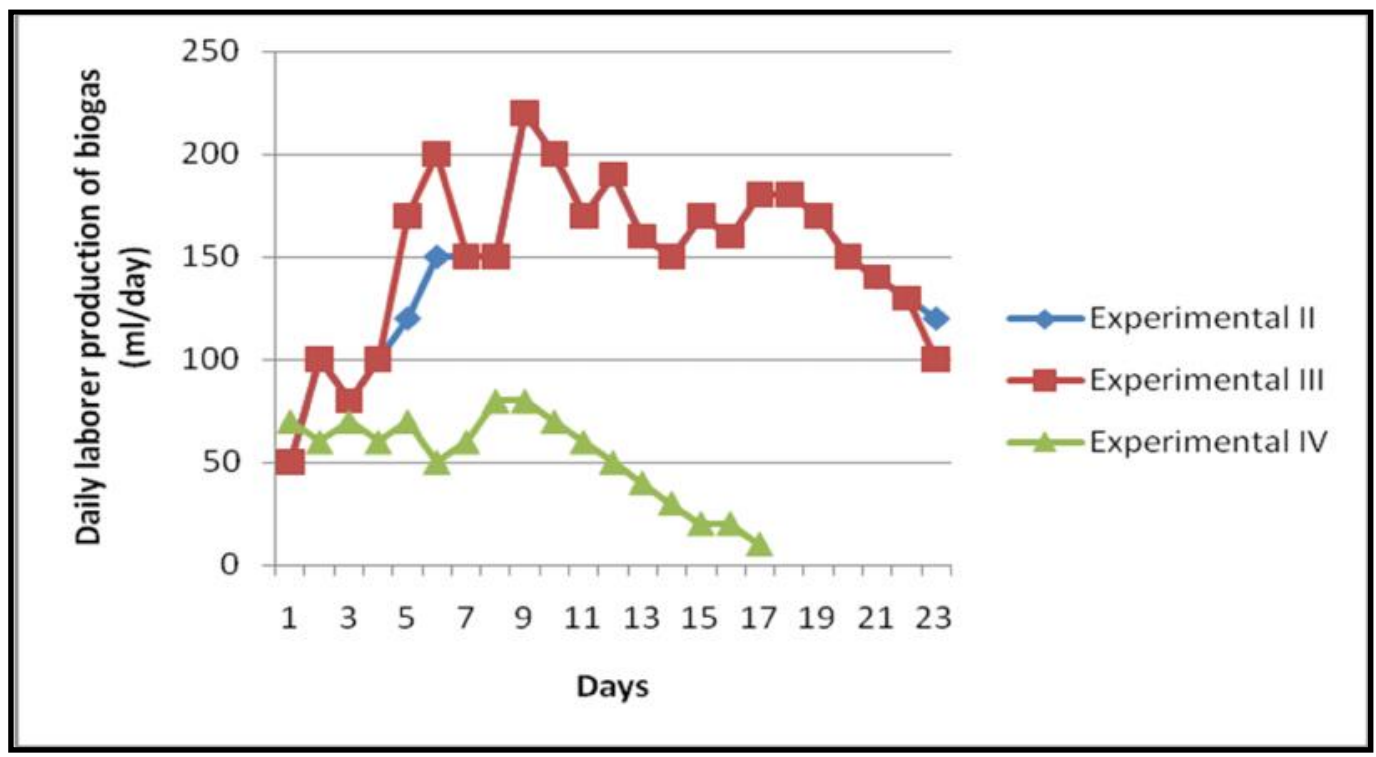

Fig.8. Evolution of the volume of biogas produced 
For digester II (6\% DM), the daily laborer production of biogas is not constant. It fluctuated around a median value, which is about $142 \mathrm{ml}$. The curve presents a peak in the 9th day of about $220 \mathrm{ml}$. For digester III (8\% DM), the median value of daily laborer production is about $147 \mathrm{ml}$. It presents two important peaks one to 6th day $(200 \mathrm{ml})$, as for the other, it is at 9th day $(220 \mathrm{ml})$. The results obtained for two digesters II and III are in conformity with the bibliography which lays down an increase in the production of biogas with the increase in the concentration of DM [26]. According to the literature, the concentration in DM of the poultry droppings in a digester cannot exceed $10 \%$. Beyond this value, the matter is dense and causes the quickly arrested of methane fermentation. This observation is justified in the case of the digester IV (16\% DM) whose median value of the daily laborer production is about $54 \mathrm{ml}$. It is a very weak production of biogas, although the concentration in DM is highest. This can be explained by the accumulation of the matter put in fermentation in the digester which causes its stopping, from the first week of the supply with the droppings and the fall of the production of biogas in the course of time.

In the studied case, when we speak about quantitative productivity of biogas resulting from the animal biomass in digesters of laboratory, there are two different scales: Large scales which correspond to the productivity recorded in the case of the avicolous droppings (Figure 8) and the smaller second correspondent with the bovine dungs (Figure 7). This makes it possible to conclude that the productivity of biogas depends on the type of OM methanized and on power of the technology of supply (or mode of digestion) of the digester. It is higher in the case of the avicolous biomass treated in a digester with an uninterrupted supply.

\subsection{EVALUATION OF QUALITATIVE ENERGY PERFORMANCE OF THE AVICOLOUS EXPERIMENTATION}

The quality of biogas is evaluated primarily by the percentage of methane $\left(\mathrm{CH}_{4}\right)$ which it contains. A biogas is much better when its percentage of $\mathrm{CH}_{4}$ is high. The quality of biogas according to [26] varies especially according to the temperature and the concentration in DM.

\subsubsection{GAS COMPOSITION}

The analyzes of composition of avicolous biogas product were carried out on the level of the two powerful digesters (II and III). The results are given in table 5. 
Table 5. Expression of the results of the composition of biogasproduced

\begin{tabular}{|l|l|l|l|}
\hline Digesters & \% $\mathbf{C H}_{\mathbf{4}}$ & \% $\mathbf{C O}_{\mathbf{2}}$ & \% $\mathbf{H}_{2} \mathbf{S}$ \\
\hline Experimental II & 63.28 & 20.00 & 16.18 \\
\hline Experimental III & 63.40 & 30.00 & 5.89 \\
\hline
\end{tabular}

The $\% \mathrm{CH}_{4}$ of biogas produced rises generally according to the increase in the concentration in DM. However, the rise is negligible. It should be noted that the $\% \mathrm{CH}_{4}$ is also influenced by other not followed parameters (report $\mathrm{C} / \mathrm{N} \ldots$...).

The $\% \mathrm{CO}_{2}$ also rose with the increase in the concentration in DM, this is explained by the dissolution of ammonia, thus raising the value of the $\mathrm{pH}$.

The $\% \mathrm{H}_{2} \mathrm{~S}$ decreased with the rise in the concentration in DM under the adopted experimental conditions. However, it is advisable to announce that this parameter is generally less low than that raised. In the actual position, such rate generates the phenomenon of corrosion and the purification of produced biogas proves strongly recommended before use.

\subsubsection{CALORIFIC VALUE}

The energy results corresponding to the evaluation of the LCV and the HCV on the level of two digesters II and III, are reported in table 6.

A light increase in the LCV and HCV according to the concentration in DM. The recorded calorific values are in conformity with those indicated by [27] which announces a fork generally between 5000 and $8500 \mathrm{kcal} / \mathrm{Nm}^{3}$.

Table 6. Results relating to the calorific values

\begin{tabular}{|l|c|c|}
\hline Digesters & $\mathrm{LCV}\left(\mathrm{kcal} / \mathrm{Nm}^{3}\right)$ & $\mathrm{HCV}\left(\mathrm{kcal} / \mathrm{Nm}^{3}\right)$ \\
\hline Experimental II & 5394 & 6011 \\
\hline Experimental III & 5429 & 6045 \\
\hline
\end{tabular}

\section{CONCLUSION}

As a whole, the results of the experiments carried out at the time of this study, relating to the biomethanisation applied to the animal biomass, show that the environmental and energy performances of a digester, some is fed into discontinuous or uninterrupted, primarily depend on 
the nature of the matters to ferment (bovine dungs or poultry droppings), of the agitation of the substrate, the temperature maintained during digestion and also the adjustment of the $\mathrm{pH}$ and the matter introduced.

It comes out from this study the essential observations hereafter.

- The sowing of the methanogenes bacteria is a paramount need for the animal manure studied for a good starting of the alkaline fermentation (inoculum used containing black bovine dungs).

- The $\mathrm{pH}$ evolves in a very accelerated way, atteignant in most case values higher than the limiting threshold of production, during the production and launching phases.

- The combined significant effect of the mode of digestion (into discontinuous or uninterrupted) and of the nature of the substrate (bovine or avicolous) on the quantitative energy performances of experimental biogas produced. In this respect, the gas productivity is higher in the case of the digesters supplied uninterrupted with the avicolous droppings.

- The quantitative evaluation of the biogas produced by the digesters of the bovine experimentation shows that the recorded maximum production of biogas is obtained with a discontinuous fermentation at a temperature equal to $35^{\circ} \mathrm{C}$ and under agitation (case of digester IV).

- The results of quantitative evaluation of the biogas produced by the avicolous experimentation show that the production, on the level of digesters II (6\% DM), III (8\% DM) and IV (16\% DM), is in agreement with the theory which envisages an increase in the production of biogas with the increase in the concentration of DM to a certain limit. It is maximum on the level of digester III, with a considerable fall in the case of digester IV.

- The effect of the concentration in DM as well on the reduction of the polluting load (SM and $\mathrm{BDO}_{5}$ ) as on the qualitative energy performances (gas composition and calorific value) of avicolous biogas produces in experiments.

\section{REFERENCES}

[1] M.S.M. Khan, Z. Kaneesamkandi, Biodegradable waste to biogas, Renewable energy option for the Kingdom of Saudi Arabia, International Journal of Innovation and Applied Studies 4 (1), 2013, 101-113. www.issr-journals.org/xplore/.../IJIAS-13-142-18.pdf 
[2] B.H. Gilroyed, Ch. Chang, A. Chu, X. Hao, Effect of temperature on anaerobic fermentative hydrogen gas production from feedlot cattle manure using mixed microflora, International journal of hydrogen energy 33, 2008, 4301-4308.

[3] F. Marechal, D. Favrat, E. Jochem, Energy in the perspective of the sustainable development: The 2000W society challenge, Resources, Conservation and Recycling 44, 2005, 245-262.

[4] G. Amand, A. Bonnouvrier, D. Chevalier, E. Dezat, C. Nicolas, P. Ponchant, Les consommations d'énergie dans les bâtiments avicoles, Quelques repères sur les consommations d'énergie et propositions de pistes d'amélioration, ITAVI 1, 2008, 24 p.

[5] S.E. Mbuligwe, G.R. Kassenga, Feasibility and strategies for anaerobic digestion of solid waste for energy production in Dar es Salaam city, Tanzania, Resources, Conservation and Recycling 42, 2004, 183-203.

[6] W.T. Tsai, Y.H. Chou, Y.M. Chang, Progress in energy utilization from agrowastes in Taiwan, Renewable and Sustainable Energy Reviews 8, 2004, 461-481.

[7] B. Amigun, H. Von Blottnitz, Investigation of scale economies for African biogas installations, Energy Conversion and Management 48, 2007, 3090-3094.

[8] J. Ko Han, Y. Ki Kim, T. Hyeon Kim, N. Chi Kim, M. Umeda, Evaluation of maturity parameters and heavy metal contents in composts made from animal manure, Waste Management 28, 2008, 813-820.

[9] Afilal M.E., Moncif M., Benyamna A. Valorisation des déchets organiques par fermentation méthanique, Revue des Energies Renouvelables CER'07 Oujda, 2007, 9-12. www.cder.dz/download/cer07_2.pdf

[10] Afilal M.E., Bakx A., Belakhdar N., Membrez Y. Evaluation of the biogas potential of organic waste in the northern provinces of Morocco, Revue des Energies Renouvelables Vol. 13 (2), 2010, 249-255. www.cder.dz/download/Art13-2 5.pdf

[11] Afilal M.E., Belkhadir N., Daoudi H., Elasri O. Fermentation méthanique des différents substrats organiques, J. Mater. Environ. Sci. Vol. 4 (1), 2013, 11-16. www.jmaterenvironsci.com/Document/vol4/2-JMES-190-2012-Afilal.pdf 
[12] M’Sadak Y., Ben M'Barek A., Zoghlami R.I. Diagnostics environnemental et énergétique des digesteurs anaérobies expérimentaux des fientes avicoles, Revue Nature \& Technologie, Janvier 2013, Numéro 8 (C), 19-26.

www.univ-chlef.dz/revuenatec/Art_08_C_03.pdf

[13] M'Sadak Y., Ben M'Barek A. Energy, environmental and agronomic valorizations of the rural biomethanisation of the bovine biomass, International Journal of Innovation and Applied Studies, October 2013, Vol. 4, No 2, 343-352. www.issr-journals.org/ijias/fr/authid.php?id=612

[14] M'Sadak Y., Zoghlami R.I. Caractérisations physico-chimique, environnementale et énergétique de la biométhanisation industrielle avicole en Tunisie semi-aride, Algerian Journal of Arid Environment (AJAE), Décembre 2012, Vol. 2, No 2, 16-27. www.univ-ouargla.dz/Pagesweb/PressUniversitaire/doc/.../E020202.pdf

[15] M.A. Oueslati, M. Ksontini, M. Haddad, Y. Charbonnel, Compostage des branches d'Acacia cyanophylla et des boues fraîches des stations d'épuration d'eaux usées, Rev. For. Fr. XLVII 5, 1995, 523-529.

documents.irevues.inist.fr/bitstream/handle/.../RFF_1995 5 523.pdf?s...

[16] P. Westerman, J. Bicudo, Management considerations for organic waste use in agriculture, Bioresour. Technol 96, 2005, 215-221.

[17] T. Kupper, J.G. Fuchs, Compost et digestat en Suisse, Publication de l'Office Fédéral de l'Environnement (OFE), Berne, Suisse, 2007, 124 p. www.bafu.admin.ch/publikationen/publikation/.../index.html?lang...

[18] A. Lehtomaki, S. Huttunen, J.A. Rintala, Laboratory investigations on co-digestion of energy crops and crop residues with cow manure for methane production: Effect of crop to manure ratio, Resources, Conservation and Recycling 51, 2007, 591-609.

[19] Sh. Satyanarayana, P. Murkutea, X. Ramakant, Biogas production enhancement by Brassica compestries amendment in cattle dung digesters, Biomass and Bioenergy 32 (2008) 210-215.

[20] A. Karagiannidis, G. Perkoulidis, A multi-criteria ranking of different technologies for the anaerobic digestion for energy recovery of the organic fraction of municipal solid wastes, Bioresource Technology 100, 2009, 2355-2360. 
[21] O. Almoustapha, J. Millogo-Rasolodimby, Production de biogaz et de compost à partir d'eichhornia crassipes, (mart) solms-laub (pontederiaceae) pour un développement durable en Afrique sahélienne, Revue Vertigo 7, 2009, 7 p.

[22] F. Ramade, Dictionnaire encyclopédique de l'écologie et des sciences de l'environnement, Édiscience internationale, Paris, 1993. www.dicoland.com/fr/

[23] R. Moletta, Contrôle et conduite des digesteurs anaérobies, Revue des Sciences de l'eau 2, 1989, 265-293. http://nelson.cen.umontreal.ca/revue/rseau/1989/v2/n2/705031ar.pdf

[24] A. Ghaly, J. Pyke, Amelioration of methane yield in cheese whey fermentation by controlling the $\mathrm{pH}$ of the methanogenic stage, Applied Biochemistry and biotechnology 27, 1991, 217-237.

[25] H. Roque, Fondements théoriques du traitement biologique des eaux, Chap. 3-6 Traitement anaérobie, 1981, 1476-1532.

[26] J. Akrout, Étude énergétique de la fermentation méthanique des fientes de volailles: optimisation des facteurs influant et modélisation du système, Doctorat de spécialisation, École Nationale des Ingénieurs de Tunis, 1992, 143 p.

[27] M. Monzambe, La problématique de la biométhanisation en République Démocratique du Congo, Université du Québec, Canada, 2002, 38 p.

classiques.uqac.ca/.../monzambe.../biomethanisation/biomethanisation.pdf

\section{How to cite this article:}

M'Sadak Y. Ben M'Barek A. Compared performances of the experimental digesters of the animal biomass. J Fundam Appl Sci. 2014, 6(1), 11-30 